\title{
Assessment of Heavy Metals Immobilization in Artificially Contaminated Soils Using Some Local Amendments
}

\author{
Noha H. Abdel-Kader, Reda R. Shahin*, Hasan A. Khater \\ Soils Department, Faculty of Agriculture, Cairo University, Giza, Egypt \\ Email: *dredashahin@gmail.com
}

Received May 17, 2013; revised June 23, 2013; accepted July 2, 2013

Copyright (C) 2013 Noha H. Abdel-Kader et al. This is an open access article distributed under the Creative Commons Attribution License, which permits unrestricted use, distribution, and reproduction in any medium, provided the original work is properly cited.

\begin{abstract}
Three alluvial soil samples with different textures were artificially polluted with chloride solutions of $\mathrm{Cd}, \mathrm{Pb}$, $\mathrm{Co}$ and chromate solution for $\mathrm{Cr}$. The aqua-regia extracted concentration ranges in the artificially polluted soils were 1134 $1489 \mathrm{mg} \cdot \mathrm{kg}^{-1}$ for $\mathrm{Pb}, 854-938 \mathrm{mg} \cdot \mathrm{kg}^{-1}$ for $\mathrm{Cr}, 166-346 \mathrm{mg} \cdot \mathrm{kg}^{-1}$ for $\mathrm{Co}$ and $44-54 \mathrm{mg} \cdot \mathrm{kg}^{-1}$ for Cd. The aqua-regia extracted metals were the highest in the spiked clay soil due to its high adsorption capacity. Rock phosphate (PR), limestone (LS) and Portland-cement (Cem) were mixed with the spiked soils at $1 \%$ and $2 \%$ rates $(\mathrm{w} / \mathrm{w})$ and incubated at 30 $\mathrm{C}$ for $2,7,14,30,60,150$ and 360 days. The extracted DTPA metals significantly decreased with different magnitudes with increasing the incubation period accompanied by increases in both $\mathrm{pH}$ and EC. The data showed that cement $(\mathrm{Cem})$ treatment dropped the DTPA-Pb from @ 1000 to @ $400 \mathrm{mg} \cdot \mathrm{kg}^{-1}$ in all the studied soils (60\% decrease) in the first 2 months while it gradually decreased from 400 to $200 \mathrm{mg} \cdot \mathrm{kg}^{-1}$ (20\% decrease) in the next 10 months. Limestone (LS) and rock phosphate (PR) materials were relatively less effective in lowering DTPA-Pb after 12 months of incubation. The data showed also that cement (Cem) treatment was the most effective one in lowering DTPA-Cd by @ 60\% as compared to the un-amended soils after 12 months of soil incubation. Extractable DTPA-Co and Cr showed consistent decreases with time down to nearly $50 \%$ of un-amended soils due to the effect of the added amendments after 12 months of incubation with superior reductions for the cement treatment in all the investigated soils. The statistical analysis confirmed that in all the studied metals and treatment, cement treatment (Cem) was significantly the most effective in lowering the DTPA extracted metals as indicated from LSD test. It was found that up to $73 \%$ and $57 \%$ of the applied $\mathrm{Pb}$ and $\mathrm{Cd}$, respectively, were fixed by only $1 \%$ cement. However, the present study showed that from the practical and economic points of view, that $1 \%$ Cement was the best treatment to immobilize $\mathrm{Pb}$ and $\mathrm{Cd}$ from all the artificially polluted soils.
\end{abstract}

Keywords: Heavy Metals; Immobilization Efficiency; Rock Phosphate; Portland Cement; Lime-Stone

\section{Introduction}

The contamination of soils with heavy metals is now worldwide concerned due to its hazard to ecosystem including soil, water, plant, animal and human life. The common international technologies of the remediation of the heavy metals contaminated sites are physical, chemical and biological techniques. The immobilization technique is commonly recognized for the in-situ remediation of heavy metals contaminated soils (Unite State Environmental Protection Agency (EPA), [1]. Immobilization is the reduction of the solubility of heavy metals through chemical reactions (ion-exchange, adsorption, precipitation and complexation processes) making them less harmful or less mobile (Hashimoto et al. [2] and

*Corresponding author.
Wang et al. [3]). The mostly applied amendments include clay material, cement, zeolites, phosphates, and organic composts GWRTAC [4] and Finžgar et al. [5]. Zhang and $\mathrm{Pu}[6]$ used limestone $(\mathrm{AL})$, rock phosphate (RP), palygorskite (PG), and calcium magnesium phosphate (CMP) to stabilize heavy metals in two urban soils (calcareous soil and acidic soil) polluted with cadmium, copper, zinc and lead for 12 months. The results showed that application of those materials reduced exchangeable forms in the order of $\mathrm{Pb}>\mathrm{Cd}>\mathrm{Cu}>\mathrm{Zn}$. Phosphate and and palygorskite treatments were more efficient than limestone and rock phosphate in stabilizing heavy metals. Padmavathiamma and Li [7] found that lime application to H.M. polluted soil lowered plant available $\mathrm{Pb}$ and $\mathrm{Mn}$, while rock phosphate decreased plant available $\mathrm{Pb}$ and increased plant Mn. Houben et al. [8] found that the ad- 
dition of $\mathrm{CaCO}_{3}$ to heavy metals contaminated soils significantly reduced both the leaching and the availability of $\mathrm{Cd}, \mathrm{Zn}$ and $\mathrm{Pb}$ metals. Chen et al. [9] applied rock phosphate with a rate of $2500 \mathrm{mg} \mathrm{P}_{2} \mathrm{O}_{5} \mathrm{~kg}^{-1}$ soil and found that it could successfully reduce the bioavailability and increase the geochemical stability of $\mathrm{Pb}, \mathrm{Zn}$ and $\mathrm{Cd}$ in soil. In addition, Chen et al. [10] showed that rock phosphate of the smallest grain size ( $<35$ microns) was superior to all of other grain sizes more than 35 microns for reducing uptake in plant (Brassica oleracea L.) shoots for $\mathrm{Cd}(19.6 \%-50.0 \%), \mathrm{Pb}(21.9 \%-51.4 \%)$ and $\mathrm{Zn}$ $(22.4 \%$ - 34.6\%), respectively, as compared with the soil without application of rock phosphate. Cao et al. [11] stated that rock phosphate amendment significantly reduced $\mathrm{Pb}$ water solubility, phyto-availability, and bioaccessibility by $72 \%-100 \%, 15 \%-86 \%$, and $28 \%-$ $92 \%$, respectively due to the formation of insoluble $\mathrm{Pb}-$ phosphate minerals and reduced water soluble $\mathrm{Cu}$ and $\mathrm{Zn}$ by $31 \%-80 \%$ and $40 \%-69 \%$, respectively. Al-Oud and Hilal [12] found that the admixing $0.5 \%$ of cement could reduce the $0.5 \mathrm{~N} \mathrm{HNO}_{3}$ extracted $\mathrm{Pb}$ by values up to $65 \%$ in the polluted sandy soils in Saudi Arabia. Alpaslan and Yukselen [13] conducted several leaching experiments for mixtures of different additives (lime, activated carbon, clay, zeolite, sand and cement) with artificially $\mathrm{Pb}$ contaminated (spiked) soil samples. They stated that lime and cement were significantly effective in $\mathrm{Pb}$ immobilization with $88 \%$ efficiency at 1:21 lime:soil ratio and $99 \%$ efficiency at 1:15 cement:soil ratio, respectively.

The objective of the present work is to evaluate the efficiency of different local amendments to stabilize or immobilize heavy metals in different soil types artificially spiked with $\mathrm{Pb}, \mathrm{Cd}, \mathrm{Cr}$ and Co heavy metals.

\section{Materials and Methods}

Three soil samples with different textures were taken from the most common polluted spots at Bahr el Bakar and Helwan. The collected samples were subjected to the physical and chemical analyses according to Sparks et al. [14] and their characteristics are presented in Table 1.

Solutions of different concentrations of cadmium $(\mathrm{Cd})$, lead $(\mathrm{Pb})$, and cobalt $(\mathrm{Co})$ were prepared using metal chlorides and $\mathrm{Cr}$ as chromate, then sprayed onto the soil samples with continuous mixing to homogenize the distribution of the applied heavy metals. The spiked soils were allowed to be air-dried after each portion of sprayed metals solution. The total amounts of the metals were applied to exceed their maximum concentrations in soils as reported by EPA [15]. After spiking, the soil was supersaturated with deionized water and then mixed periodically for two weeks. The wetting and air dry cycle procedure was repeated five times to allow sufficient mixing of the applied metals and soil to imitate field conditions (Shanbleh and Kharabsheh, [16]; Lin et al.,
[17]). The aqua regia extraction was conducted and based on the procedure recommended by Cottenie et al. [18] which standardized by the International Organization for Standardisation (ISO 11466, [19]). In this procedure the soil sample intake was of $1 \mathrm{~g}$, which were placed in 100 $\mathrm{ml}$ Pyrex digestion tubes, then $3 \mathrm{ml}$ distilled water was added to obtain slurry. Thereafter, $7.5 \mathrm{ml}$ of $37 \% \mathrm{HCl}$ and $2.5 \mathrm{ml}$ of $70 \% \mathrm{HNO}_{3}(3: 1)$ mixture were added to the tube which was covered and left overnight. Then, the suspension was digested at $130^{\circ} \mathrm{C}$ for $2 \mathrm{~h}$, in a reflux condenser. The obtained suspension was then filtered through an ashless Whatman 41 filter, diluted to $25 \mathrm{ml}$ with $0.5 \mathrm{~mol} \cdot \mathrm{L}^{-1} \mathrm{HNO}_{3}$, and stored in polyethylene bottles at $4^{\circ} \mathrm{C}$ for analyses.

The available metal contents of soils were extracted in DTPA (diethylene-triamine-penta-acetic acid) according to Lindsay and Norwell [20] as modified by ISO 14870 [21]. The DTPA-TEA solution was prepared by mixing of $0.005 \mathrm{~mol} \cdot \mathrm{L}^{-1} \mathrm{DTPA}, 0.01 \mathrm{~mol} \cdot \mathrm{L}^{-1} \mathrm{CaCl}_{2}, 0.1 \mathrm{~mol} \cdot \mathrm{L}^{-1}$ tri-ethanolamine (TEA) with $\mathrm{pH}$ adjusted to 7.3 with 1 $\mathrm{mol} \cdot \mathrm{L}^{-1} \mathrm{HCl}$ solution. An amount of $5 \mathrm{~g}$ of soil sample $(<2 \mathrm{~mm})$ was weighted into a $125 \mathrm{~mL}$ Erlenmeyer flask, then $20 \mathrm{ml}$ of DTPA-TEA extracting solution was added and shaken for $2 \mathrm{~h}$ at room temperature using a platform shaker. The soil suspension was centrifuged at $2000 \mathrm{rpm}$ for $15 \mathrm{~min}$. and the clear supernatant was diluted to 50 $\mathrm{mL}$ with re-distilled water. Both aqua-regia and DTPAextractable contents were determined by a Perkin-Elmer model 1100B flame atomic absorption spectrometer (AAS).

Analysis of variance and LSD were used to compare treatment means. All the statistical analyses were carried out using Costat software [22].

The chemical and physical properties of the artificially contaminated soils are presented in Table 2.

Three local amendments were chosen, i.e. Phosphate rock (PR), Limestone (LS), and Portland cement (Cem). Portions of $100 \mathrm{~g}$ from the artificially contaminated soils were mixed with $1 \mathrm{~g}$ and $2 \mathrm{~g}$ of each amendment. A control treatment $\left(C_{0}\right)$ for each soil with no amendment addition was also prepared. Each treatment was carried out in triplicates. Replications of the homogeneous soil mixtures were watered to saturation level and placed in sealed small polyethylene bags in order to maintain the moisture level. The sealed soil mixture bags were incubated for $2,7,14,30,60,150$ and 360 days at $31^{\circ} \mathrm{C} \pm$ $2^{\circ} \mathrm{C}$. The soil bags were thoroughly mixed during the incubation process. At each period, a replicate from each treatment was removed from the incubator and the DTPA-TEA extractable fractions of the studied metals in soils were determined after incubation. The difference in initial concentration and final concentration, knowing dry mass of soil, allowed for the calculation of the exact amount of heavy metals adsorbed per gram of soil. A standard solution was run with each batch to justify the 
Table 1. Some physical and chemical characteristics of the initial soil samples.

\begin{tabular}{|c|c|c|c|c|c|c|c|c|}
\hline \multirow[t]{2}{*}{ Soil texture } & \multicolumn{3}{|c|}{ Particle size fraction $(\mathrm{g} / \mathrm{kg})$} & \multirow{2}{*}{$\begin{array}{c}\mathrm{pH} \\
(1: 2.5)\end{array}$} & \multirow{2}{*}{$\mathrm{EC} \mathrm{dS} / \mathrm{m}$} & \multirow{2}{*}{$\begin{array}{c}\mathrm{OM} \\
(\mathrm{g} / \mathrm{kg})\end{array}$} & \multirow{2}{*}{$\begin{array}{c}\mathrm{CaCO}_{3} \\
(\mathrm{~g} / \mathrm{kg})\end{array}$} & \multirow{2}{*}{$\begin{array}{c}\mathrm{CEC} \\
\mathrm{Cmol} / \mathrm{kg}\end{array}$} \\
\hline & Sand & Silt & Clay & & & & & \\
\hline Sandy L. & 748 & 144 & 108 & 7.79 & 1.14 & 1.5 & 11.6 & 9.4 \\
\hline Loamy & 460 & 378 & 162 & 7.83 & 1.94 & 11.3 & 22 & 33.6 \\
\hline \multirow[t]{3}{*}{ Clay } & 424 & 90 & 486 & 7.55 & 3.66 & 26.6 & 3.26 & 48.1 \\
\hline & \multicolumn{2}{|c|}{$\mathrm{Cd}(\mathrm{mg} / \mathrm{kg})$} & \multicolumn{2}{|c|}{$\mathrm{Pb}(\mathrm{mg} / \mathrm{kg})$} & \multicolumn{2}{|c|}{$\mathrm{Co}(\mathrm{mg} / \mathrm{kg})$} & \multicolumn{2}{|c|}{$\mathrm{Cr}(\mathrm{mg} / \mathrm{kg})$} \\
\hline & Aqua-Regia & DTPA & Aqua-Regia & DTPA & Aqua-Regia & DTPA & Aqua-Regia & DTPA \\
\hline Sandy L. & 1.02 & 0.08 & 20.3 & 0.3 & 3.2 & 0.53 & 16.3 & 7.37 \\
\hline Loamy & 2.01 & 0.14 & 46 & 1.3 & 5.5 & 0.67 & 11.12 & 4.13 \\
\hline Clay & 3.03 & 0.03 & 10.5 & 0.1 & 5.68 & 0.45 & 9.32 & 2.5 \\
\hline
\end{tabular}

Table 2. The chemical characteristics of the spiked soil samples and the different amendments used in the incubation experiment.

\begin{tabular}{|c|c|c|c|c|c|c|c|c|c|c|c|}
\hline & & \multirow{2}{*}{$\begin{array}{c}\mathrm{pH} \\
1: 2.5\end{array}$} & \multirow{2}{*}{$\begin{array}{c}\mathrm{EC} \\
\mathrm{dS} / \mathrm{m}\end{array}$} & \multicolumn{2}{|c|}{$\mathrm{Pb}(\mathrm{mg} / \mathrm{kg})$} & \multicolumn{2}{|c|}{$\mathrm{Cd}(\mathrm{mg} / \mathrm{kg})$} & \multicolumn{2}{|c|}{$\mathrm{Co}(\mathrm{mg} / \mathrm{kg})$} & \multicolumn{2}{|c|}{$\mathrm{Cr}(\mathrm{mg} / \mathrm{kg})$} \\
\hline & & & & Aqua-Regia & DTPA & Aqua-Regia & DTPA & Aqua-Regia & DTPA & Aqua-Regia & DTPA \\
\hline \multirow{3}{*}{ Spiked soils } & Sandy loam & 8.85 & 10.4 & 1134.2 & 1027.2 & 44.53 & 34.65 & 165.70 & 23.97 & 854.4 & 189.10 \\
\hline & Loamy & 8.58 & 5.0 & 1421.1 & 1008.3 & 52.71 & 31.65 & 229.30 & 18.62 & 878.2 & 153.80 \\
\hline & Clay & 8.44 & 26.4 & 1488.9 & 988.4 & 54.09 & 23.13 & 346.10 & 7.70 & 938.0 & 67.20 \\
\hline \multirow{3}{*}{ Amendment } & P-Rock & & & 2.1 & 0.004 & 4.80 & 0.11 & 1.26 & ND & 3.5 & 0.03 \\
\hline & Limestone & & & 3.0 & 0.017 & 0.16 & 0.02 & 0.08 & ND & 7.1 & 0.08 \\
\hline & Cement & & & 9.3 & 0.230 & 0.10 & 0.008 & 4.78 & 0.007 & 18.1 & 0.12 \\
\hline
\end{tabular}

$\mathrm{ND}=$ Not detected.

data. The efficiency $(E)$ of different amendments for immobilization heavy metals can be evaluated using the expression:

$$
E(\%)=\left[\left(C_{0}-C_{12}\right) / C_{0}\right] \times 100
$$

where $E=$ immobilization efficiency $\% ; C_{12}=$ equilibrium extractable concentration $\left(\mathrm{mg} \cdot \mathrm{kg}^{-1}\right)$ of single metal in the amended soil at the end of incubation experiment (12 months); $C_{0}=$ initial extractable concentration $\left(\mathrm{mg} \cdot \mathrm{kg}^{-1}\right)$ of single metal in the amended soil at zero time.

\section{Results and Discussion}

The data of the spiked soil samples, showed tremendous increases in the Aqua-regia extracted $\mathrm{Pb}, \mathrm{Cd}, \mathrm{Co}$ and $\mathrm{Cr}$ proportional to their applied amounts. Table 2 showed that the aqua-regia extracted metal concentrations were the highest in the clay soil due to its high adsorption capacity for all the tested heavy metals and the vice versa for the sandy soil. The highest concentration was recorded for $\mathrm{Pb}$ and the least for $\mathrm{Cd}$ in the different soils in the order: $\mathrm{Pb}>\mathrm{Cr}>\mathrm{Co}>\mathrm{Cd}$. This is due to the high geochemical affinity of $\mathrm{Pb}$ to react with soil constituents forming inner-sphere complexes and even precipitate in different forms. In contrast to $\mathrm{Pb}, \mathrm{Cd}$ tend to be less and weakly adsorbed by different soils which facilitate its leaching (Irha et al. [23]). Table 2 indicated that the concentrations of the labile heavy metal forms (i.e. DTPA-extracted) were higher in the spiked sandy soil compared to clay one due to the lack of adsorping/active surfaces in sandy soil. Li-Yi et al. [24], Mbarki et al. [25] and Selim [26] concluded that the free heavy metal ion concentrations in sandy soils were higher than in clay one receiving the same pollutants. Figure 1 showed the initially adsorbed concentrations in the spiked soils for the investigated metals. These values were obtained by subtracting The DTPA from Aqua-regia extracted heavy metal concentrations. It was clearly noticed the clay soil initially adsorbed the highest concentrations of all the investigated heavy metals while sandy one adsorbed the lowest values. Again, chromium $(\mathrm{Cr})$ and lead $(\mathrm{Pb})$ showed the highest concentrations initially adsorbed in all the investigated soils which may rendered to their high adsorption affinity and the formation of innersphere complexes with the active surfaces of soil constituents. This is in agreement with Gomes et al. [13] whom observed that in a competitive situation $\mathrm{Cr}$ and $\mathrm{Pb}$ were the heavy-metal cations most strongly adsorbed by seven Brazilian soils, whereas $\mathrm{Cd}, \mathrm{Ni}$, and $\mathrm{Zn}$ were the least adsorbed.

The obtained data showed that the application of the 
different amendments had a significant effect on $\mathrm{pH}$ value of all the studied soils (Figure 2). Generally, in all
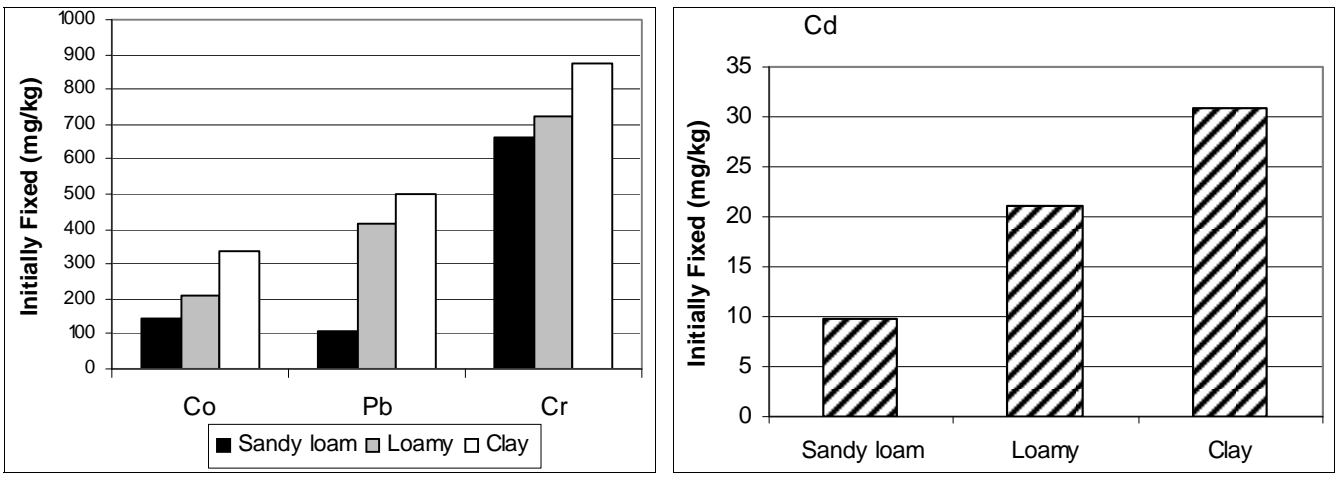

Figure 1. Initially fixed heavy metal concentrations in the artificially contaminated soils.
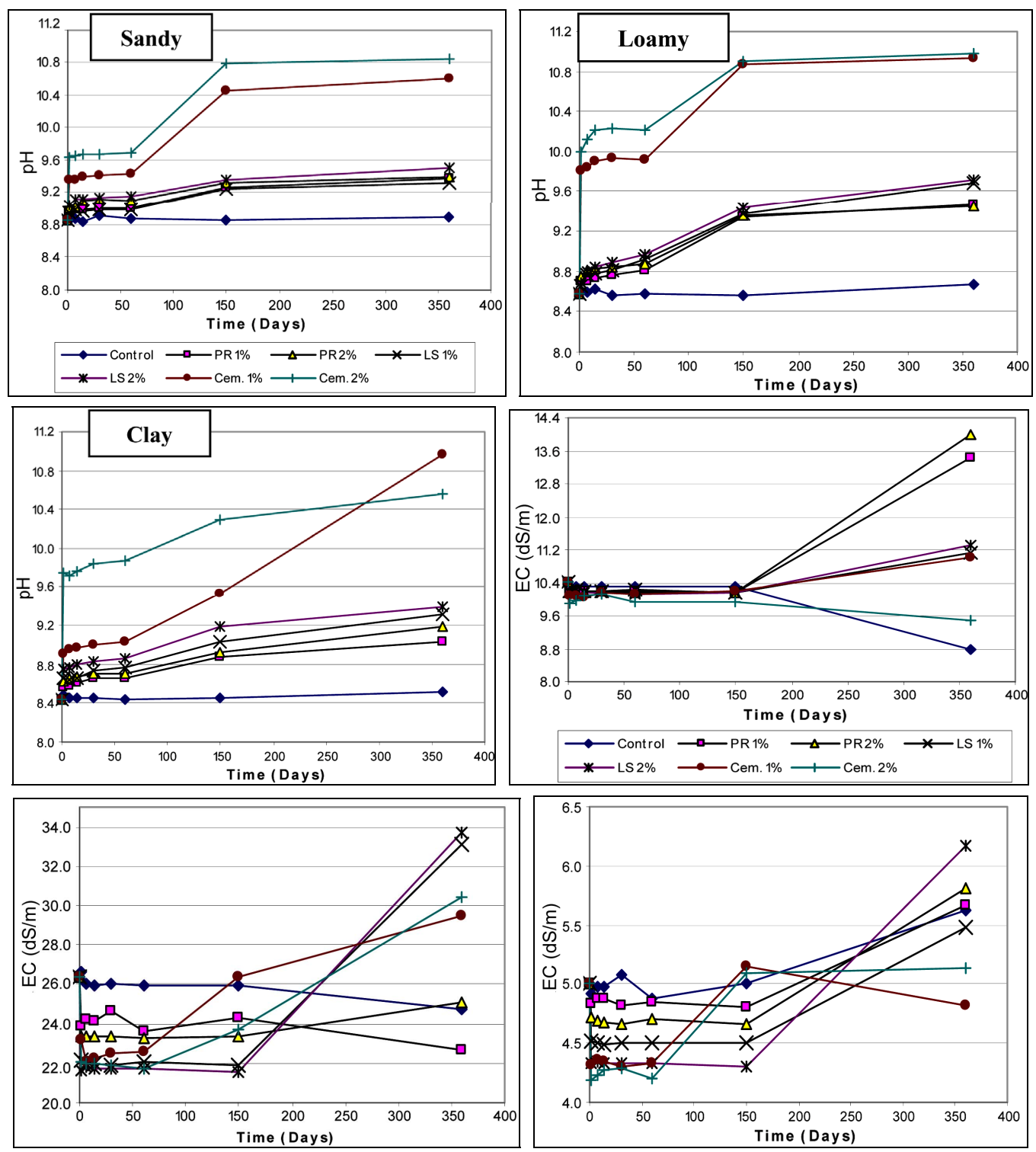

Figure 2. Changes of $\mathrm{pH}$ and $\mathrm{EC}$ of the polluted soils throughout the incubation periods as affected by the applied rates of the local amendments. 
150 days followed by steady increases upto 360 days. Soil $\mathrm{pH}$ value increased with increasing application rates of amendments. When the same rates of amendments were applied, the $\mathrm{pH}$ values increased in the sequence of $\mathrm{Cem}>\mathrm{LS}>\mathrm{PR}$. With respect to $\mathrm{pH}$ changes in the investigated soils, significantly the highest $\mathrm{pH}$ values were recoded in the sandy soil as compared to the same treatments in the clay one. This could be rendered to the low buffering capacity of sandy soils and the lack of reserve acidity that can alleviate the alkalinity effect of the applied amendments. In addition, the initial $\mathrm{pH}$ values of the artificially polluted soil were more than 8.44 and 8.85 , which may limit the buffering action to the bases produced from the hydrolysis of the highly alkaline components of Portland cement. Tylor [27] stated that there are four chief minerals present in a Portland cement grain: tricalcium silicate $\left(\mathrm{Ca}_{3} \mathrm{SiO}_{5}\right)$, dicalcium silicate

$\left(\mathrm{Ca}_{2} \mathrm{SiO}_{4}\right)$, tricalcium aluminate $\left(\mathrm{Ca}_{3} \mathrm{Al}_{2} \mathrm{O}_{5}\right)$ and calcium aluminoferrite $\left(\mathrm{Ca}_{4} \mathrm{Al}_{\mathrm{n}} \mathrm{Fe}_{2-\mathrm{n}} \mathrm{O}_{7}\right)$. The initial increase of $\mathrm{pH}$ is typical of cementitious systems because the cement produces high amount of $\mathrm{Ca}(\mathrm{OH})_{2}$; and high concentration of hydroxyl ions (Brown [28] and Tylor [27]) as in the following reactions:

Tricalcium silicate

$$
\begin{aligned}
& 2(\mathrm{CaO})_{3}\left(\mathrm{SiO}_{2}\right)+7 \mathrm{H}_{2} \mathrm{O} \\
& \rightarrow(\mathrm{CaO})_{3}\left(\mathrm{SiO}_{2}\right)_{2} \cdot 4 \mathrm{H}_{2} \mathrm{O}+3 \mathrm{Ca}(\mathrm{OH})_{2}
\end{aligned}
$$

Dicalcium silicate

$$
\begin{aligned}
& 2(\mathrm{CaO})_{3}\left(\mathrm{SiO}_{2}\right)+5 \mathrm{H}_{2} \mathrm{O} \\
& \rightarrow(\mathrm{CaO})_{3}\left(\mathrm{SiO}_{2}\right)_{2} \cdot 4 \mathrm{H}_{2} \mathrm{O}+\mathrm{Ca}(\mathrm{OH})_{2}
\end{aligned}
$$

Tricalcium aluminate

$$
\begin{aligned}
& 2(\mathrm{CaO})_{3}\left(\mathrm{SiO}_{2}\right)+7 \mathrm{H}_{2} \mathrm{O} \\
& \rightarrow(\mathrm{CaO})_{3}\left(\mathrm{SiO}_{2}\right)_{2} \cdot 4 \mathrm{H}_{2} \mathrm{O}+3 \mathrm{Ca}(\mathrm{OH})_{2}
\end{aligned}
$$

The incubation of the amended soils also caused general increases in EC values with time in most of the investigated amendments (Figure 2). Limestons (LS) treatments showed the highest EC values followed by Cement (Cem.) as shown in loamy and clay soils and $\mathrm{EC}$ values increased by increasing the percent of application. It is clearly noticed that the majority of EC increases were recorded between 150 and 360 days of incubation period which could be rendered to the hydrolysis and solubility of Ca-compounds that may take longer time. The presence of siliceous-aluminous materials in cement composition creates some kind of high adsorption sites for metals found in soils. Moreover, the production of calcium hydroxide during cement hydrolysis, increase $\mathrm{pH}$ of the treated soils and subsequently decreasing the bioavailability of heavy metals in soils. Figure 3 Showed that cement $(\mathrm{Cem})$ treatment dropped the DTPA-Pb from @ 1000 to @ $400 \mathrm{mg} / \mathrm{kg}$ in all the studied soils (60\% decrease) in the first 2 months while it gradually decreased from 400 to $200 \mathrm{mg} / \mathrm{kg}$ ( $20 \%$ decrease) in the next 10 months. Limestone (LS) and rock phosphate (PR) materials were relatively less effective in lowering DTPA-Pb after 12 months of incubation. The data showed also that cement (Cem) treatment was the most effective one in lowering DTPA-Cd by @ 60\% as compared to the unamended soils after 12 months of soil incubation.

Extractable DTPA-Co and Cr (Figure 4) showed con-
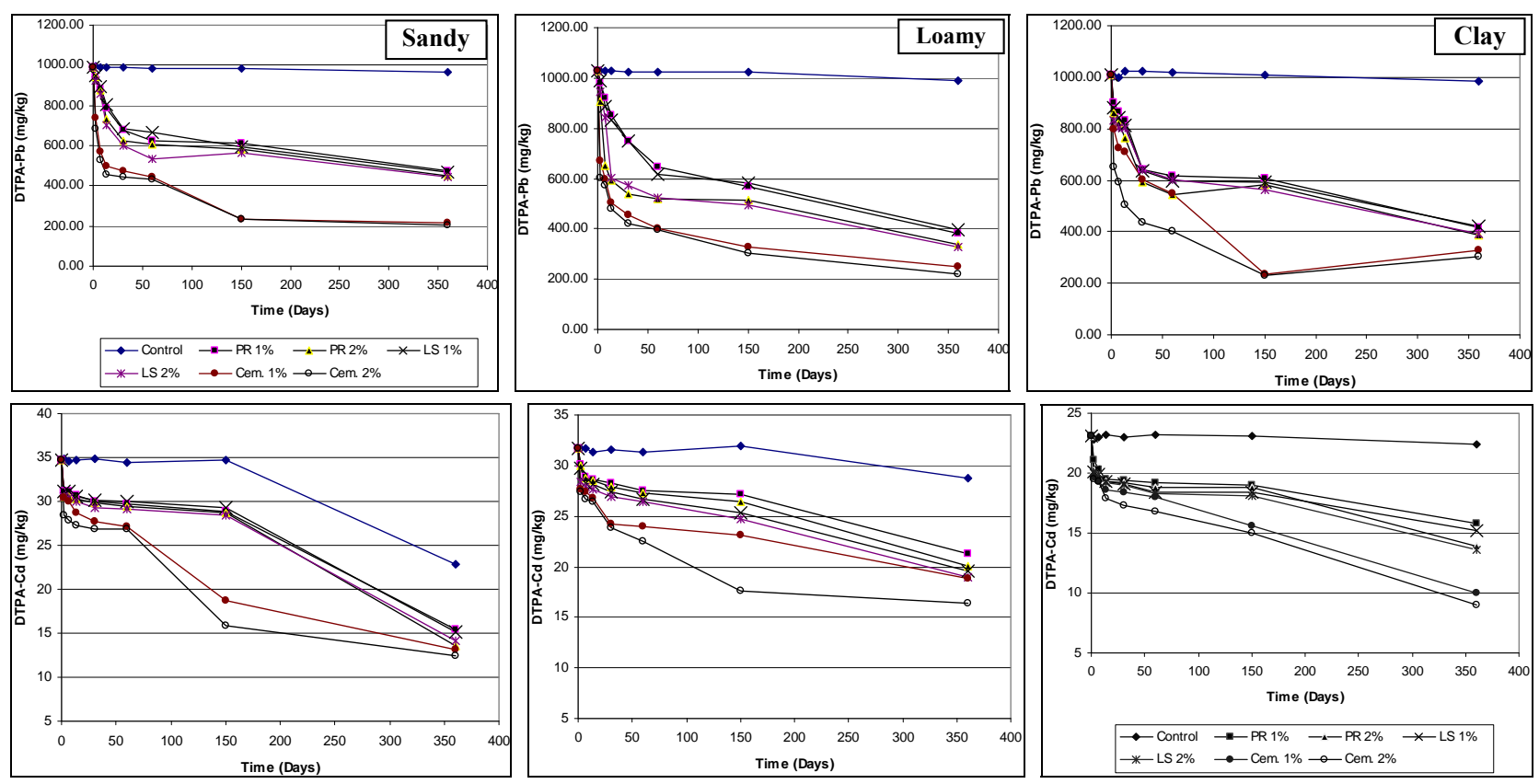

Figure 3. Changes of pH and EC of the polluted soils throughout the incubation periods as affected by the applied rates of the local amendments. 

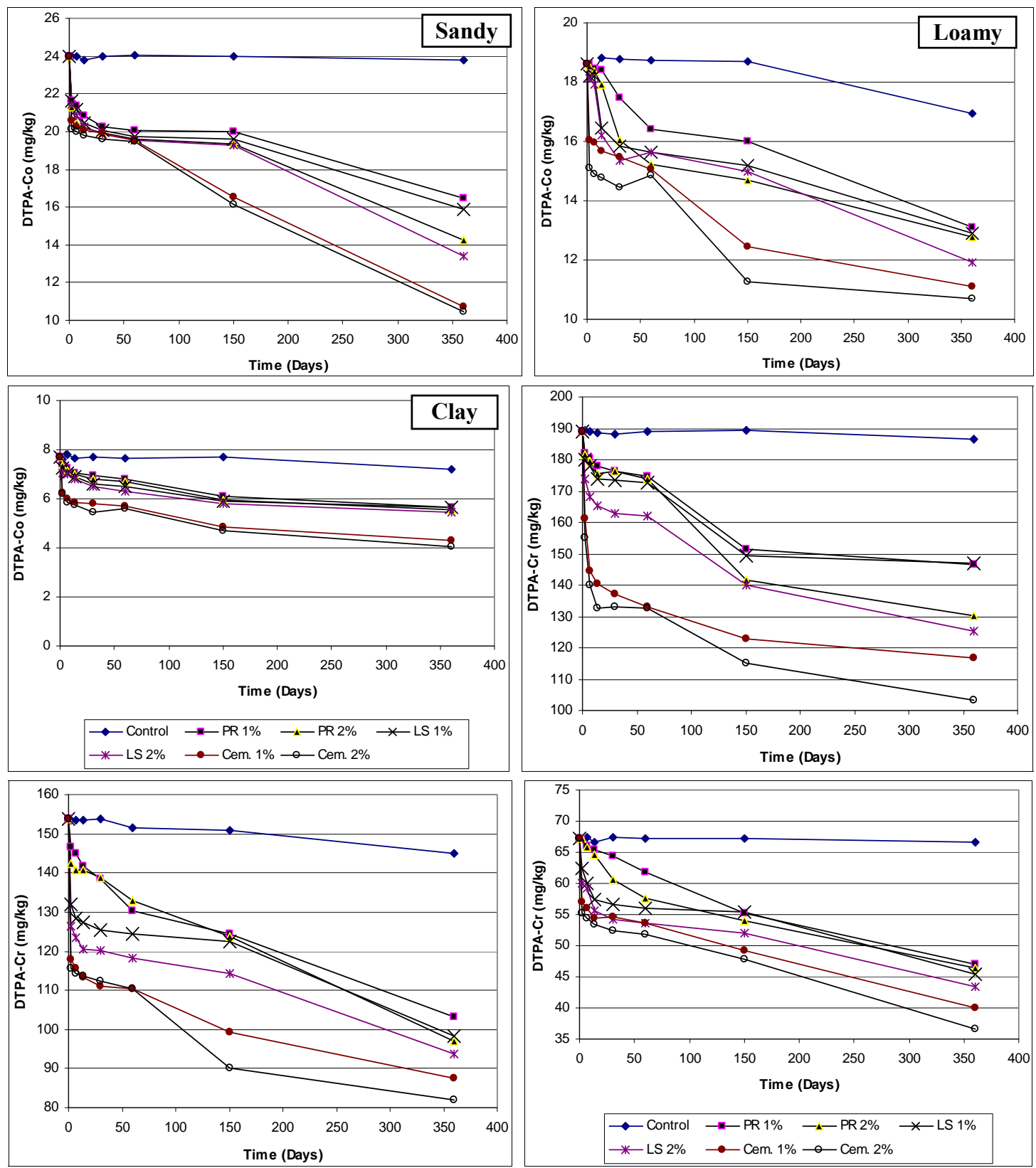

Figure 4. Extractable DTPA-Co and $\mathrm{Cr}$ from the polluted soils throughout the incubation periods as affected by the applied rates of the local amendments.

sistent decreases with time down to nearly $50 \%$ of unamended soils due to the effect of the added amendments after 12 months of incubation with superior reductions for the cement treatment in all the investigated soils. The statistical analysis (Table 3) confirmed that in all the studied metals and treatment, cement treatment $(\mathrm{Cem})$ was significantly the most effective in lowering the DTPA extracted metals as indicated from LSD test.

In addition, LSD test showed that cement treatment was significantly decreased all the DTPA extractable metals, and the increased of the applied cement from 1 to $2 \%$ didn't show any significant differences, which indi- cated that only $1 \%$ of cement was enough to get the lowest DTPA extracted metals in all the investigated soils.

Table 4 showed the heavy metals concentrations that immobilized by the effect of the different local amendments, it was obtained by subtracting concentration at the end of the incubation experiment i.e. 12 months $\left(C_{12}\right)$ from the relevant concentration in the polluted soil at zero time $\left(C_{0}\right)$, so amendment immobilized metal $=\left(C_{0}\right)$ $\left(C_{12}\right)$. The obtained data showed that the immobilized concentrations by the different amendments could be in the order: $\mathrm{Pb}>\mathrm{Cr}>\mathrm{Cd}>\mathrm{Co}$ in all the studied treatments. Again, it could be concluded that cement (Cem) had the 
Table 3. LSD analysis of the mean concentrations of different metals in the different treatments and soils at the end of the incubation experiment.

\begin{tabular}{|c|c|c|c|c|c|c|c|c|c|}
\hline \multirow{3}{*}{$\begin{array}{c}\begin{array}{c}\text { Soil } \\
\text { type }\end{array} \\
\text { Sandy }\end{array}$} & \multirow{3}{*}{$\begin{array}{c}\begin{array}{c}\text { Treatment } \\
\text { symbol }\end{array} \\
\text { Control }\end{array}$} & \multicolumn{8}{|c|}{ Concentration ( $\mathrm{mg} / \mathrm{kg}$ soil) } \\
\hline & & \multicolumn{2}{|c|}{$\mathrm{Pb}$} & \multicolumn{2}{|c|}{$\mathrm{Cd}$} & \multicolumn{2}{|c|}{$\mathrm{Co}$} & \multicolumn{2}{|c|}{$\mathrm{Cr}$} \\
\hline & & 990.6 & $\mathrm{a}$ & 34.67 & $\mathrm{a}$ & 23.960 & $\mathrm{a}$ & 153.1 & $\mathrm{a}$ \\
\hline & PR $1 \%$ & 795.9 & $\mathrm{~b}$ & 30.97 & $\mathrm{~b}$ & 21.159 & $\mathrm{~b}$ & 140.1 & $\mathrm{~b}$ \\
\hline & PR $2 \%$ & 787.2 & $\mathrm{~b}$ & 30.91 & $\mathrm{~b}$ & 20.939 & $\mathrm{~b}$ & 139.0 & $\mathrm{~b}$ \\
\hline & LS $1 \%$ & 763.8 & $\mathrm{~b}$ & 30.59 & $\mathrm{~b}$ & 20.730 & $\mathrm{~b}$ & 130.6 & $\mathrm{c}$ \\
\hline & LS $2 \%$ & 738.4 & $\mathrm{~b}$ & 30.35 & $\mathrm{~b}$ & 20.677 & $\mathrm{~b}$ & 125.2 & $\mathrm{c}$ \\
\hline & Cem 1\% & 563.8 & $\mathrm{c}$ & 28.19 & $\mathrm{bc}$ & 20.121 & $\mathrm{~b}$ & 117.4 & $\mathrm{~d}$ \\
\hline & Cem $2 \%$ & 538.0 & $\mathrm{c}$ & 26.81 & $\mathrm{c}$ & 19.870 & $\mathrm{~b}$ & 115.8 & $\mathrm{~d}$ \\
\hline \multicolumn{2}{|c|}{ LSD 0.05} & \multicolumn{2}{|c|}{99.1} & \multicolumn{2}{|c|}{2.29} & \multicolumn{2}{|c|}{0.913} & \multicolumn{2}{|c|}{7.4} \\
\hline \multirow[t]{8}{*}{ Loamy } & Control & 1026.6 & $\mathrm{a}$ & 31.587 & $\mathrm{a}$ & 18.64 & $\mathrm{a}$ & 188.9 & $\mathrm{a}$ \\
\hline & PR $1 \%$ & 821.2 & $\mathrm{~b}$ & 28.899 & $\mathrm{~b}$ & 17.71 & $\mathrm{ab}$ & 175.9 & $\mathrm{~b}$ \\
\hline & PR $2 \%$ & 812.2 & $\mathrm{~b}$ & 28.640 & $\mathrm{~b}$ & 17.05 & $\mathrm{~b}$ & 174.0 & $\mathrm{~b}$ \\
\hline & LS $1 \%$ & 715.9 & $\mathrm{bc}$ & 28.154 & $\mathrm{bc}$ & 16.89 & $\mathrm{~b}$ & 173.7 & $\mathrm{~b}$ \\
\hline & LS $2 \%$ & 677.7 & $\mathrm{c}$ & 27.650 & $\mathrm{bc}$ & 16.69 & $\mathrm{~b}$ & 165.9 & $\mathrm{~b}$ \\
\hline & Cem 1\% & 570.0 & $\mathrm{~d}$ & 26.401 & $\mathrm{~cd}$ & 15.61 & c & 146.9 & $\mathrm{c}$ \\
\hline & Cem 2\% & 543.7 & $\mathrm{~d}$ & 25.171 & $\mathrm{~cd}$ & 14.85 & $\mathrm{c}$ & 142.5 & $\mathrm{c}$ \\
\hline & LSD 0.05 & \multicolumn{2}{|c|}{104.5} & \multicolumn{2}{|c|}{1.532} & \multicolumn{2}{|c|}{0.98} & \multicolumn{2}{|c|}{9.8} \\
\hline \multirow[t]{8}{*}{ Clay } & Control & 1012.6 & $\mathrm{a}$ & 23.064 & $\mathrm{a}$ & 7.689 & $\mathrm{a}$ & 67.16 & $\mathrm{a}$ \\
\hline & PR $1 \%$ & 770.1 & $\mathrm{~b}$ & 20.221 & $\mathrm{~b}$ & 7.039 & $\mathrm{~b}$ & 63.83 & $\mathrm{~b}$ \\
\hline & PR $2 \%$ & 760.6 & $\mathrm{~b}$ & 19.901 & $\mathrm{~b}$ & 6.949 & $\mathrm{~b}$ & 62.42 & $\mathrm{~b}$ \\
\hline & LS $1 \%$ & 736.2 & $\mathrm{~b}$ & 19.760 & $\mathrm{~b}$ & 6.847 & $\mathrm{~b}$ & 59.31 & $\mathrm{c}$ \\
\hline & LS $2 \%$ & 722.1 & $\mathrm{~b}$ & 19.654 & $\mathrm{~b}$ & 6.737 & $\mathrm{~b}$ & 57.39 & $\mathrm{cc}$ \\
\hline & Cem 1\% & 687.8 & $\mathrm{~b}$ & 18.961 & $\mathrm{bc}$ & 6.016 & c & 55.98 & $\mathrm{~cd}$ \\
\hline & Cem $2 \%$ & 572.2 & $\mathrm{c}$ & 18.406 & $\mathrm{c}$ & 5.890 & $\mathrm{c}$ & 54.61 & $\mathrm{~d}$ \\
\hline & LSD 0.05 & \multicolumn{2}{|c|}{88.7} & \multicolumn{2}{|c|}{0.943} & \multicolumn{2}{|c|}{0.354} & \multicolumn{2}{|c|}{2.85} \\
\hline
\end{tabular}

*Means within a column followed by the same letter are not significantly different; according to Fisher's protected LSD test at $p \leq 0.05$.

Table 4. Immobilized concentrations of heavy metals in different polluted soils amended with local materials $\left(C_{0}-C_{12}\right)$ mg.kg ${ }^{-1}$.

\begin{tabular}{ccccccccc}
\hline & & PR 1\% & PR 2\% & LS 1\% & LS 2\% & Cem 1\% & Cem 2\% & Initial-DTPA \\
\hline Clay & $\mathrm{Co}$ & 2.23 & 2.90 & 2.40 & 3.16 & 3.97 & 4.04 & 7.70 \\
$\left(C_{0}-C_{12}\right)$ & $\mathrm{Cd}$ & 7.42 & 9.18 & 7.63 & 8.71 & 9.70 & 10.33 & 23.13 \\
& $\mathrm{Cr}$ & 13.21 & 18.77 & 13.09 & 20.29 & 23.22 & 27.74 & 67.20 \\
& $\mathrm{~Pb}$ & 568.04 & 598.55 & 565.29 & 594.16 & 658.17 & 682.94 & 988.4 \\
& $\mathrm{Co}$ & 5.05 & 5.47 & 5.30 & 6.62 & 7.66 & 8.21 & 18.62 \\
$\left(C_{0}-C_{12}\right)$ & $\mathrm{Cd}$ & 7.39 & 8.67 & 9.08 & 9.71 & 9.87 & 12.31 & 34.65 \\
& $\mathrm{Cr}$ & 41.82 & 47.96 & 46.55 & 51.25 & 57.51 & 62.77 & 153.80 \\
& $\mathrm{~Pb}$ & 604.71 & 649.80 & 594.35 & 660.28 & 740.60 & 768.4 & 1008.3 \\
$\left(C_{0}-C_{12}\right)$ & $\mathrm{Co}$ & 3.81 & 4.16 & 3.86 & 4.38 & 7.22 & 7.88 & 23.97 \\
& $\mathrm{Cd}$ & 9.64 & 12.40 & 10.42 & 12.85 & 18.06 & 19.53 & 31.65 \\
& $\mathrm{Cr}$ & 55.07 & 56.70 & 59.50 & 64.39 & 73.39 & 81.85 & 189.10 \\
& $\mathrm{~Pb}$ & 494.02 & 517.69 & 498.23 & 526.02 & 753.36 & 762.99 & 1027.2 \\
\hline
\end{tabular}


most effective immobilization in all the investigated heavy metals polluted soils. Cobalt $(\mathrm{Co})$ and chromium (Cr) showed the lowest response to the added amendments as their immobilized concentrations were 2.23 to 8.21 and 13.2 to $81.85 \mathrm{mg} \cdot \mathrm{kg}^{-1}$, respectively, as compared to that of immobilized $\mathrm{Pb}$-concentrations (494.02 to $762.99 \mathrm{mg} \cdot \mathrm{kg}^{-1}$ ).

Figure 5 showed that the immobilization efficiency $\left(E(\%)=\left[\left(C_{0}-C_{12}\right) / C_{0}\right] \times 100\right)$ of lead $(\mathrm{Pb})$ was the highest $(67 \%-73 \%)$ among the other heavy metals in all the investigated soils especially those treated with cement. The immobilization efficiency for Cd was $28.48 \%$ - 57.06\%, for $\mathrm{Cr}$ it was $34.55 \%-38.81 \%$ and for Co it ranged between $30.12 \%-51.56 \%$ of the initial DTPA concentrations were fixed by only $1 \%$ cement. However, the present study showed that from the paractical and economic points of view, that $1 \%$ Cement was the best treatment to immobilize $\mathrm{Pb}$ and $\mathrm{Cd}$ from all the artificially polluted soils.

According to Ganjidoust et al. [29], it is found that the hydrating cement product enhances the heavy metals precipitation on the surfaces of their particles as shown in Figure 6. Lead $(\mathrm{Pb})$ and $\mathrm{Cd}$ were found in stabilized forms of $\mathrm{Ca}_{2} \mathrm{~Pb}_{2} \mathrm{O}_{5}(\mathrm{OH})_{2}$, and $\mathrm{CaCd}(\mathrm{OH})_{4}$, respectively.

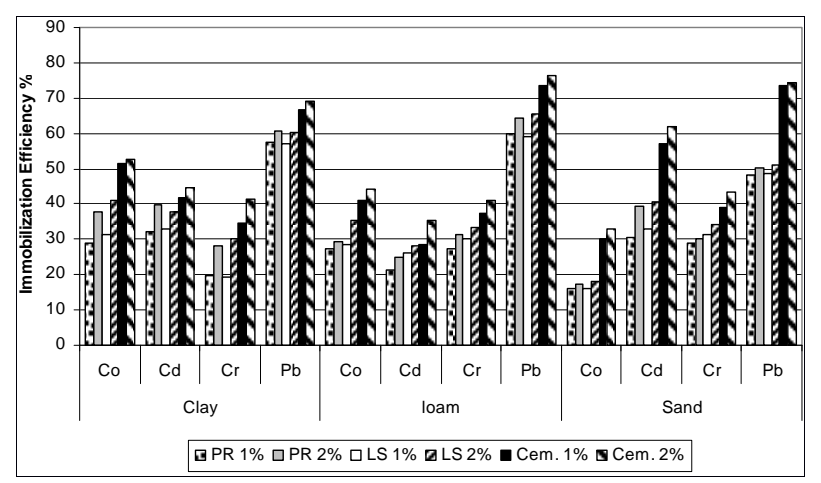

Figure 5. The efficiency of the heavy metals immobilization for different types and rates of local amendments.

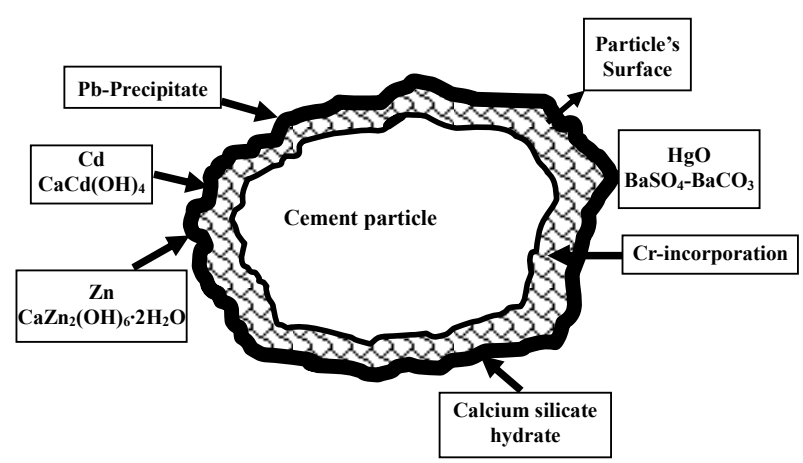

Figure 6. Immobilization of heavy metals by hydrated particle of Portland cement as suggested by Ganjidoust et al. (2009).
In addition, Komisarek and Wiatrowska [30] stated that cementitious material has the potential ability to immobilize heavy metals by adsorption, precipitation surface complexation and isomorphous substitution.

\section{REFERENCES}

[1] United States Environmental Protection Agency, "Olidification/Stabilization Resource Guide," Office of Solid Waste and Emergency Response (5102G), 1999. www.epa.gov, clu-in.org

[2] Y. Hashimoto, H. Matsufuru, M. Takaoka, H. Tanida and T. Sato, "Impacts of Chemical Amendment and Plant Growth on Lead Speciation and Enzyme Activities in a Shooting Range Soil: An X-Ray Absorption Fine Structure Investigation," Journal of Environmental Quality, Vol. 38, No. 4, 2009, pp. 1420-1428.

[3] Q. L. Wang, L. Luo, Y. B. Ma, D. P. Wei and L. Hua, “In Situ Immobilization Remediation of Heavy Metals-Contaminated Soils: A Review," Chinese Journal of Applied Ecology, Vol. 20, No. 5, 2009, pp. 1214-1222.

[4] N. Finžgar, B. Kos and D. Leštan, "Bioavailability and Mobility of $\mathrm{Pb}$ after Soil Treatment with Different Remediation Methods," Plant, Soil and Environment, Vol. 52, No. 1, 2006, pp. 25-34.

[5] GWRTAC, "Remediation of Metals-Contaminated Soils and Groundwater," Tech. Rep. TE-976-01, Pittsburgh, GWRTAC Series. 1997.

[6] M. Zhang and J. Pu, "Mineral Materials as Feasible Amendments to Stabilize Heavy Metals in Polluted Urban Soils," Journal of Environmental Sciences, Vol. 23, No. 4, 2011, pp. 607-615.

[7] P. K. Padmavathiamma and L. Y. Li, "Phytoavailability and Fractionation of Lead and Manganese in a Contaminated Soil after Application of Three Amendments," Bioresource Technology, Vol. 101, No. 14, 2010, pp. 56675676.

[8] D. Houben, J. Pircar and P. Sonnet, "Heavy Metal Immobilization by Cost-Effective Amendments in a Contaminated Soil: Effects on Metal Leaching and Phyto-Availability," Journal of Geochemical Exploration, Vol. 123, 2012, pp. 87-94. doi:10.1016/j.gexplo.2011.10.004

[9] S. Chen, M. Xu, Y. Ma and J. Yang, "Evaluation of Different Phosphate Amendments on Availability of Metals in Contaminated Soil," Ecotoxicology and Environmental Safety, Vol. 67, No. 2, 2007, pp. 278-285.

[10] S. B. Chen, Y. G. Zhu and Y. B. Ma, "The Effect of Grain Size of Rock Phosphate Amendment on Metal Immobilization in Contaminated Soils," Journal of Hazardous Materials, Vol. 134, No. 1-3, 2006, pp. 74-79.

[11] X. Cao, A. Wahbi, L. Ma, B. Li and Y. Yang, "Immobilization of $\mathrm{Zn}, \mathrm{Cu}$ and $\mathrm{Pb}$ in Contaminated Soils Using Phosphate Rock and Phosphoric Acid," Journal of Hazardous Materials, Vol. 164, No. 2-3, 2009, pp. 555-564.

[12] S. S. Al-Oud and M. I. D. Helal, "Immobilization of Pb in Polluted Soils Using Natural and Synthetic Chemical Additives," National Groundwater Association (NGWA) Conference on Remediation, New Orleans, 13-14 November 
2003.

[13] B. Alpaslan and M. A. Yukselen, "Remediation of Lead Contaminated Soils by Stabilization/Solidification," $\mathrm{Wa}$ ter, Air and Soil Pollution, Vol. 133, No. 1-4, 2002, pp. 253-263.

[14] D. L. Sparks, "Soil Science Society of America, and American Society of Agronomy, Methods of Soil Analysis. Part 3, Chemical Methods," Soil Science Society of America Book Series, No. 5, Madison, 1996.

[15] Environmental Protection Agency, "Integrated Risk Information System (IRIS)," National center for Environmental Assessment, Office of Research and Development, Washington DC, 2001.

[16] A. Shanbleh and A. Kharabsheh, "Stabilization of Cd, Ni and $\mathrm{Pb}$ in Soil Using Natural Zeolite," Journal of Hazardous Material, Vol. 45, No. 11, 1996, pp. 207-217.

[17] C. F. Lin, S. S. Lo, H. Y. Lin and Y. Lee, "Stabilization of Cadmium Contaminated Soil Using Synthesized Zeolite," Journal of Hazardous Material, Vol. 60, No. 10, 1998, pp. 217-226.

[18] A. Cottenie, M. Verloo, L. Kiekens, G. Velgh and R. Camerlynch, "Chemical Analysis of Plants and Soils," Lab. Anal. Agrochem. State Univ. Ghent Belgium, 1982.

[19] ISO 11466, "Soil Quality, Extraction of Trace Elements Soluble in Aqua Regia," International Organization for Standardization, 1995.

[20] W. L. Lindsay and W. A. Norwell, "Development of a DTPA Soil Test for Zinc, Iron, Manganese and Copper," Soil Science Society of America Journal, Vol. 42, No. 3, 1978, pp. 421-428. doi:10.2136/sssaj1978.03615995004200030009x

[21] ISO 14870, "Soil Quality_Extraction of Trace Elements by Buffered DTPA Solution," International Organization for Standardization, 2001.

[22] Costat 2.1, "CoHort Software," 2005. http://www.Cohort.com/Costat.html
[23] N. Irhaa, E. Steinnesb, U. Kirsoa and V. Petersellc, "Mobility of $\mathrm{Cd}, \mathrm{Pb}, \mathrm{Cu}$, and $\mathrm{Cr}$ in Some Estonian Soil Types," Estonian Journal of Earth Sciences, Vol. 58, No. 3, 2009, pp. 209-214.

[24] L. Yi, Y. Hong, D. Wang and Y. Zhu, "Determination of Free Heavy Metal Ion Concentrations in Soils around a Cadmium Rich Zinc Deposit," Geochemical Journal, Vol. 41, 2007, pp. 235-240. doi:10.2343/geochemj.41.235

[25] S. Mbarki, N. Labidi, H. Mahmoudi, N. Jedidi and C. Abdelly, "Contracting Effects of Municipal Compost on Alfalfa Growth in Clay and Sandy Soils: N, P, K Content and Heavy Metal Toxicity," Bioresource Technology, Vol. 99, No. 15, 2008, pp. 6745-6750.

[26] H. M. Selim, "Competitive Sorption and Transport of Trace Elements in Soils and Geological Media," CRC/ Tylor and Francis, Boca Raton, 2012. doi:10.1201/b13041

[27] H. F. W. Taylor, "Cement Chemistry," 2nd Edition, Academic Press, London, 1997. doi:10.1680/cc.25929

[28] P. W. Brown, "Early Hydration of Tetracalcium Aluminoferrite in Gypsum and Lime Gypsum Solutions," Journal of the American Ceramic Society, Vol. 70, No. 7, 1987, pp. 493-496.

http://ciks.cbt.nist.gov/garbocz/cell1994/node18.htm doi:10.1111/j.1151-2916.1987.tb05682.X

[29] H. Ganjidoust, A. Hassani and A. R. Ashkiki, "CementBased Solidification/Stabilization of Heavy Metal Contaminated Soils with the Objective of Achieving High Compressive Strength for the Final Matrix," Transaction Civil Engineering, Vol. 16, No. 2, 2009, pp. 107-115. http://www.sid.ir/en/VEWSSID/J_pdf?95520092A05.pdf

[30] J. Komisarek and K. Wiatrowska, "Effectiveness of Oxide-Amendments in the Stabilization Process of $\mathrm{Cu}, \mathrm{Pb}$ and Zn in Artificially Contaminated Soil," Polish Journal of Environmental Studies, Vol. 18, No. 6, 2009, pp. 10291038. http://www.pjoes.com/pdf/18.6/1029-1038.pdf 